\title{
SMART CITIES, INTERNET OF THINGS AND PERFORMATIVE SENSIBILITY. BRIEF ANALYSIS ON GLASGOW, CURITIBA AND BRISTOL'S INITIATIVES'.
}

\author{
André Lemos ${ }^{2}$ \\ Faculty of Communication at Federal University of Bahia
}

\begin{abstract}
Smart cities initiatives are based on strong narratives fostered by companies and governments to deploy digital technologies in a way to improve economic growth and sustainability, as well as to maintain a better control, surveillance, and efficient usage of urban resources. It is a mix of business innovation, technocratic discourses, big data and internet of things hype. Many projects are currently being carried out and celebrated around the globe. With Internet of Things (IoT) and Big Data deployment in the core of Smart Cities initiatives (digital things, algorithms, operational systems, control rooms...), we now have to deal with a new feature of objects: their performative sensibility. Based on my observation of three smart cities initiatives (Glasgow, Curitiba, and Bristol), I would like to point out to a specific issue on the social and political dimensions of objects' invisibility in everyday life. I propose here a very preliminary theoretical background in order to analyse the public participation and the object's invisibility in those cities. I'll put a strong emphasis on the Internet of Things and the changing in the nature of objects. In my preliminary analysis, informational-enhanced objects are not clearly in "handiness". This invisibility is in the core of the "algorithm governmentality".
\end{abstract}

Keywords: Smart Cities. Internet of things. Algorithm governmentality. Performative sensibility.

\section{CIDADES INTELIGENTES, INTERNET DAS COISAS E SENSIBILIDADE PERFORMATIVA: ANÁLISE DE INICIATIVAS EM GLASGOW, CURITIBA E BRISTOL}

\begin{abstract}
Resumo
As iniciativas de cidades inteligentes baseiam-se em fortes narrativas promovidas por empresas e governos para implantar tecnologias digitais de forma a melhorar o crescimento econômico e a sustentabilidade, bem como manter um melhor controle, vigilância e uso eficiente dos recursos urbanos. É uma mistura de inovação empresarial, discursos tecnocráticos, big data e internet de coisas. Muitos projetos estão sendo realizados e celebrados em todo o mundo. Com a Internet das Coisas (IoT) e a implantação de Big Data no núcleo das iniciativas das Cidades Inteligentes (coisas digitais, algoritmos, sistemas operacionais, salas de controle ...), temos agora de lidar com uma nova característica dos objetos: sua sensibilidade performativa. Com base na minha observação de três iniciativas de cidades inteligentes (Glasgow, Curitiba e Bristol), gostaria de assinalar uma questão específica sobre as dimensões sociais e políticas da invisibilidade dos objetos na vida cotidiana. Proponho aqui um quadro teórico muito preliminar para analisar a participação pública e a invisibilidade do objeto nessas cidades. Vou colocar uma forte ênfase na Internet das Coisas e na mudança na natureza dos objetos. Na minha análise preliminar, objetos informacional-realçados não estão claramente em "manuseabilidade". Esta invisibilidade está no núcleo da "governantabilidade algorítmica"
\end{abstract}

Palavras chave: Cidades inteligentes. Internet das coisas. Governantabilidade algorítmica. Sensibilidade performativa

\footnotetext{
${ }^{1}$ This paper is based on a research carried out by an academic collaboration between Brazil and UK Universities, financed by the Newton Fund (PUCPR, UFBA, Durham and Plymouth). It is focused at the intersection of two interconnected research areas — smart technologies and smart cities. We visited and had workshops in Glasgow/Durham, Curitiba, Paraná; Bristol/Plymouth. What I show here do not represent the opinion of the network and is based on a very preliminary analysis.

${ }^{2}$ Full professor at Faculty of Communication at Federal University of Bahia, CNPQ Research Fellow (PQ-1A).
}

P2P \& INOVAÇÃO, Rio de Janeiro, v. 3 n. 2, p.80-95, Mar./ Set. 2017. 


\section{Introduction}

As Jane Bennett (2010) puts in "The Vibrant Matter. A Political ecology of Things," we have to face two questions when dealing with objects today: 1. Philosophical - how take seriously the objects away from an idea of passive stuff? 2. Political - how political solutions to public problems (privacy, institutional control, government's surveillance...) change when we take seriously the vitality and the agency of the new objects? These are crucial questions today because we are in the midst of a strong development of new kinds of objects with the Internet of Things (IoT), and Big Data (the realm of algorithm as a new powerful and invisible "thing" that have strong agency in all sectors of society — as we all saw here at our first seminar about "autocracy")! Unfortunately, I'll just touch these two questions today. Actually, they are central for my long-term research that I'm calling "the communication of things".

We have to address these philosophical and political issues because everything is being transformed in digitally enhanced objects, driven by algorithm (a thing in itself as well), making us acting accordingly. As Bruno Latour (2005) argues, for understand the social we have to put, analytically, at the same level human and non human actants ("everything that modify another entity in a trial") to see which values emerge in a given association. These values cannot be defined in advance or by ontological qualities (thing — passive, subject — active), but from their performances in a specific association. For James the "pragmatic method" is "the attitude of looking away from first things, principles, 'categories', supposed necessities; and of looking towards last things, fruits, consequences, facts" (JAMES, 1981, p. 29). Also, this is the main idea of Actor-Network Theory (ANT): highlight humans and non humans' mediation to understand the network's associations (association is what Latour calls "social") looking away from big principles, categories, or frames.

Consequently, what happens when digitally enhanced objects/things communicate autonomously with each other (IoT), harvest a huge amount of information (Big Data), acting in an invisible way from the humans (subjects), generating agency and new associations? New associations build new societies. That's why we tag or society as an "information society," a "digital society," or a "cyber society". Things are never passive, but today they have a new informational quality that produce new forms of agency and associations. We have to probe the secret life of objects because their agency affects the secret life of ourselves. This paper begins where Ash, Kitchin and Leszczynski's (2015) finished their recent paper: 
In particular, we believe geographers are uniquely placed to interrogate the materiality of digital computation in innovative ways. Geographers' theorisations of space, time and relationally can be fruitfully developed to consider how digital computation and its associated objects are both singular things, with particular capacities, that also create shared space times for both other technical objects and the humans who use those objects. In other words, geographers can attend to the work that non-human infrastructures perform that always exceeds the technical parameters of their performance.

\section{Internet of Things and Performative Sensibility}

The Internet of Things; imagine a world where everything can be both analogue and digitally approached - reformulates our relationship with objects - things - as well as the objects themselves. Any object that carries an RFID tag relates not only to you, but also through being read by a RFID reader nearby, to other objects, relations or values in a database. In this world, you are no longer alone, anywhere (De Wall, et all, 2012)

Internet of Things (IoT) could be defined as a dynamic global network infrastructure with self configuring capabilities based on standard and interoperable communication protocols where physical and virtual 'things' have identities, physical attributes, and virtual personalities and use intelligent interfaces, and are seamlessly integrated into the information network. In the IoT, 'things' are expected to become active participants in business, information and social processes where they are enabled to interact and communicate among themselves and with the environment by exchanging data and information 'sensed' about the environment, while reacting autonomously to the 'real/physical world' events and influencing it by running processes that trigger actions and create services with or without direct human intervention (CERP's, 2009, p.6)

As Goergescu and Popescul explain, "the biggest problem is that IoT does not concern objects only; it is about the relations between the everyday objects surrounding humans and humans themselves. It's important to emphasise that the majority of connected objects are not always personal and are unattended" (2015). I do not have to insist, we already know, IoT is the new revolution. Some are projecting that we'll have more than 75 billions of objects connected by 2020 (Popescul, Goergescu, 2013). Let's take a look at figure 1 and 2 (Popescul, Goergescu, 2013) to see this new revolution: 


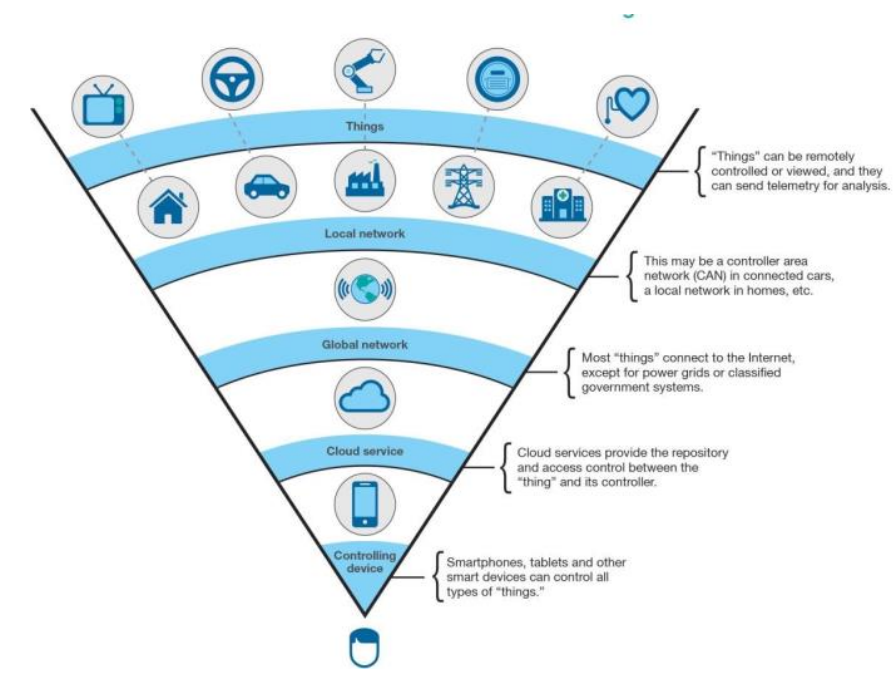

Figure 1: IBM Model for Internet of Things (IBM X-Force Threat Intelligence Quarterly, 2014)

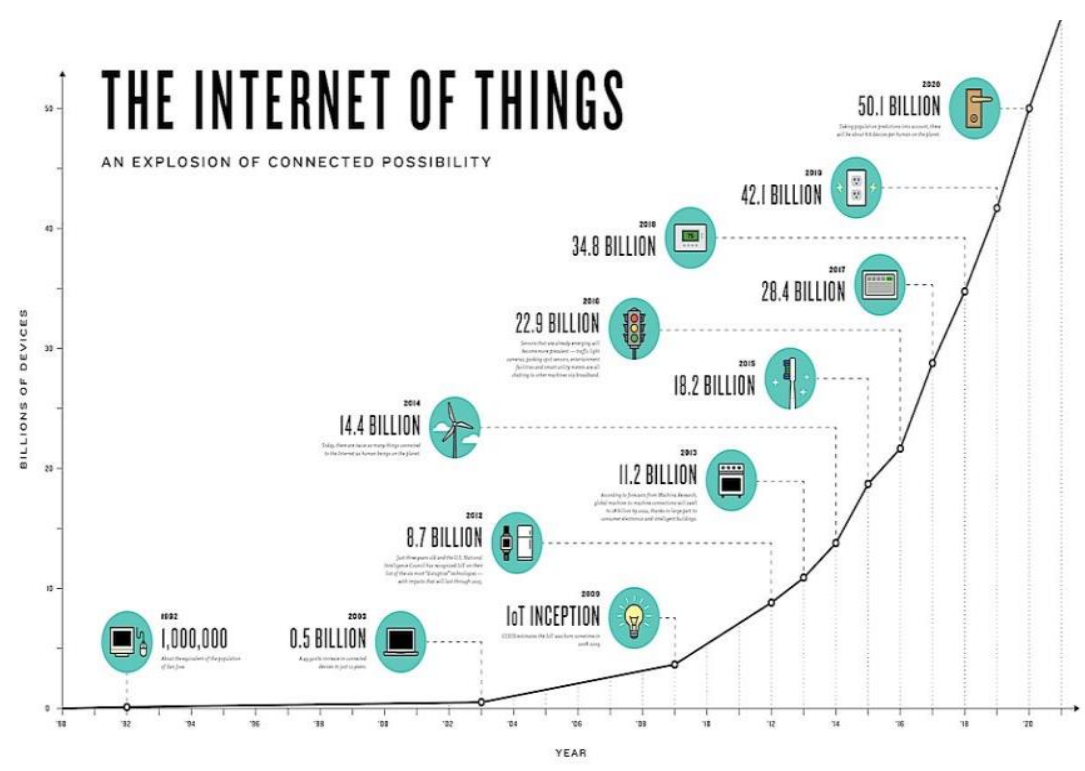

Figure 2: The evolution of connections via Internet of Things (Brandon, 2015)

Needless to say that this is only a buzz word, because we don't have an "Internet of Things," nor an "Internet of humans". The internet is a hybrid socio-technical network that brings together humans and non humans (protocol, software, machines, cables, satellites...) in strong translations and regimes of delegation, as all socio-technical network ${ }^{3}$. Despite the non accuracy of the concept of "internet of things," we can understand it. This is an expression that

\footnotetext{
${ }^{3}$ These are ANT's strong concepts and very important here. Summing up, translation is the term used to overcome divisions between socio-technical domains. It says that technology cannot be presupposed as an autonomous thing (it crosses domains such as political, social, natural, cultural). Translation makes connections, establishing communication between such domains. Delegation is a reciprocal relationship between the social and the technical. We delegate to technologies the work of many humans. In turn, technologies delegate behaviour back onto the social. For Latour (1991, 1992): "Delegation, then, is a particular instance of translation whereby the social and the technical co-constitute each other - to read the social from the technical is similarly to read the technical from the social."
} 
indicates that everything (objects, things, machines) can be digitally enhanced, that objects can be globally connected through digital networks, that they can perform actions autonomously, translating, mediating, communicating, and delegating action to other things (humans included). Objects become "smart" (can take context related decisions), they sense and communicate, they have identities (assigned identification numbers and names), a self (always defined by others), they produce information and agency. They become alive, with their own personality and behaviour. Consequently, is not out of purpose perceive them as "beings" (KARIMOVA, SHIRKHANBEIK, 2015). They have a new feature: a performative sensibility (LEMOS, 2016).

The concept of "performative sensibility" recognizes that every object has a life and that the real object is unreachable (HARMAN, 2011). This sensibility is performative because it is. procedural $^{4}$ (Manovich, 2013) in a vast actor-network ${ }^{5}$ creating "personal data practices" (Lupton, 2015). Performative sensibility it's a way the data are captured, transmitted and stored. IoT can be defined as a network, as an apparatus (discourse, marketing, business, ecology of platforms, networking, protocols, things...) driven by this performative sensibility. The performative sensibility is not exclusively the sensor's quality embedded in an object, but the performance of this object by the internet in an actor-network.

IoT is part of Smart City project (along with cloud computing and Big Data). It is important to investigate, philosophically and politically, how engage in process of mediation, translation and delegation in an urban space creating a "community of things". This idea is proposed in a recent article (KARIMOVA, SHIRKHANBEIK, 2015) in which they claim: "things can be perceived as beings within the communication networks; IoT can be organised into CoT; and various models of communities can be generated depending on desired outcomes" (p.2). CoT is a "community of things", "a group of things that shares common goals or interests and creates a social universe with its own values, rules, and vocabulary that is in a constant transformation and communication within time/space matrix" (p.5). We can think of Smart Cities as a CoT.

\footnotetext{
${ }^{4}$ The term procedural is used in the sense in which it is used by Bogost (2007) and Murray (2003), i.e., to characterize a form of symbolic expression that uses procedures peculiar to the computing environment rather than the usual processes of representation through written or spoken languages. For Bogost (2007, loc. 203-209), "Murray uses the term procedural to refer to the computer's 'defining ability to execute a series of rules'. Procedurality in this sense refers to the core practice of software authorship. Software is composed of algorithms that model the way things behave. (...) Procedural systems generate behaviours based on ruled-based models (...) Procedurality is the principal value of the computer, which creates meaning through the interaction of algorithms."

${ }^{5}$ A group of important mediators in a given action (LATOUR, 2012).
} 
Things are acquiring an unprecedented quality: the info-communicational power that produce performative sensibilities that allows objects to communicate and create mediation, translation, delegation and agency throughout algorithm performativity, autonomously, through space and time by digital networks. Objects are now capable of new forms of communication ("smart"), they are differently sensible to the context (identify differences and can react accordingly), and can affect (talk, communicate) a global audience of people or other objects ${ }^{6}$.

This new object produces new forms of agency, and here the issue of invisibility can be highlighted. We know that the secret life of objects, the real object, is never accessible. We have, consequently, to investigate them, as proposed by Bennett, politically and philosophically. Philosophically, we have to accept that objects do things, that our society emerges from human and non human associations. They are not neutral or completely domesticated by an autonomous subject ("they will do what we want to")! New digital qualities appear and change the way objects deal with other objects and humans. This new quality of objects (info-communication qualities) outcomes actions that drive our life today. We can see that this new "algorithm governmentality" (individual tracking systems, smart house, smart cars, smart cities) forges new subjectivities. The age of "smart-everything" is an age in which "smartness" is transforming our subjectivity (personal data, health performance, constraints to do or to have smart things...). That's a new form of the "care of the self" ("souci de soi," as Foucault called in his "History of Sexuality, vol. 3," 1986).

Politically this new "contract" between humans, objects and digitally enhanced objects must be clear. To bring the smart objects to a regime of visibility, we have to see them as a "matter of concern," not as a "matter of things" (passive object). "Matter of concern" means that we understand that objects making us make things, and making institutions make thinks for or against us - harvesting of personal data, creating proactive trends that affect, now and tomorrow, our lives, etc.) (LATOUR, 2005). Matter of concern is also take "thing" from the Latin roots of the word: "coisa," or "causa", cause. It means to take the new smart object's feature seriously. Objects are exploding in new performative (sensibility) actions. Knorr-Cetina (2001) argues that new objects are important mediators, that they are changing and losing their

\footnotetext{
${ }^{6}$ Note that Douglas Coupland, in The Age of Earthquakes creates a concept of Smupid and Stuart. Smupid (adj) Smart and stupid. "Smupidity defines the mental state wherein we acknowledge that we've never been smarter as individuals and yet somehow we've never felt stupider. One possible explanation is that people are generally far more aware than they ever were of all the information they don't know. Stuart (adj) Stupid and smart. We've all been in stuart situations yet have not had the word to describe it. (...) The essence of stuartivity is that one gets comfortable knowing which things one no longer needs to know-your car's licence plate number, sports statistics and recipes, for example - and hence doesn't waste brain cells remembering". See http://www.theguardian.com/education/shortcuts/2015/feb/22/glossary-for-extreme-present-online-world
} 
objectivity. I quote: "Objects of knowledge in many fields have material instantiations, but they must simultaneously be conceived as unfolding structures of absences as things that continually 'explode' and 'mutate' into something else, and that are as much defined by what they are not as by what they are" (p. 528).

Let's go back to Bennett. It is necessary to think philosophically (the ontology of the quasi-subjects or quasi-objects, as Michel Serres puts it), as well as politically about new forms of association with the IoT revolution. We have to bring objects to visibility, make them a "matter of concern". This issue is materialised in Smart Cities' initiatives.

\section{Smart Cities: Glasgow, Bristol and Curitiba}

We have witnessed a rapid and aggressive development of mobile communication systems, cloud computing, Big Data and Internet of Things. While in the 1990s we spoke of digital cities, today the emerging term is smart cities. Smart city stresses the "communication of things," and the enhanced digitally objects' agency. How city is translated in code and how code is shaping our cities? We can think code as objects, and code always attached to other objects, so the problem is how digital objects change the urban life and how urban life has been translated in digital objects. Algorithms and objects with sensors, we know, are at the core of smart cities' initiatives.

Smart city projects are public and private initiatives in which objects, infrastructure and services are electronically enhanced, backed by a strong technocratic narrative in which the emphasis is on how these technologies implemented in the urban fabric are the main factor for changing. The adjective "smart" refers exactly to this new performative sensibility of objects and to the new digital process to organise urban life. All the official narratives (government, companies) are saying that's good because this will improve the quality of our cities. We've heard this utopia already in the past. It's a pretty common technological determinism. It is a mix of business innovation, technocratic discourses, big data and internet of things hype. So, lets take a look at three real cities (Glasgow, Curitiba and Bristol). I don't have time here to give you a full detailed description of those cities. My aim here is to address the danger of invisibility in one of the main aspect: the lack of a substantial public participation, and the invisibility of the digital objects. 


\section{Glasgow}

In March 2015, we visited the Glasgow Operations Centre (part of the Future City Glasgow program), Future Cities Institute at University of Strathclyde, and Urban Tide (a private consultancy that was formed from the team that planned and delivered OPEN Glasgow programme). The city of Glasgow won the Innovate UK's $£ 24$ million TSB funding. Reading "The Open Data Manifesto" and other folders that advertise the Future City of Glasgow, we get the impression of a lively, creative, and participatory project, but the promises of an opening up of pre-existing government data, the production of new data in synergy with society, were vested by a technocratic discourse hesitating between freedom and collaboration. The main product seems to be a huge surveillance project for monitoring public space: The Glasgow Operation Centre (GOC). In fact, most of the time, money, effort, and visibility went to the updating of the system of surveillance already in place (new HD cameras). Judging by what was shown to us during the visit, there is a lack of clear objectives and low public participation. People were not data providers (as advertised), but object of monitoring and, more generally, "data sources". No real forum for community groups or businesses to become involved, beyond some hackathons, no real use of Facebook and Twitter for instance.

The focus in the end comes back to cameras and the logic of command and control. The thing we heard less about, during the whole day, was what the people of Glasgow wanted, needed and thought about the project. Glasgow had become invisible and de-spatialized into an abstract set of problems. We were never heard anything that would directly refer to places and specific areas (despite the use of CCTV's surveillance) or would reveal an attention to place and specific communities. We doubt that the people of Glasgow is aware of sensors and IoT projects going on.

The city remains invisible. Which concrete problems does the Future City Glasgow project aim to solve? What its citizens, organisations, and civil society demand? What is there about this experience that makes it unique? What cultural, social and political dimensions does the current project address? Do people in Glasgow aware of CCTV and sensors deployed throughout the city?

\section{Curitiba}


In July 2015, we visit the project "Curitiba Smart City" by the Secretary of Information and Technology at URBS (local transit and transport authority), CICCR (a Control Centre implemented in all 12 host cities to the FIFA World Cup in 2014, by the Federal Government in Brazil), the "Cyclists Pocket Square" (an initiative of a group of bike activists with the use of social media and sharing/open software, in an old abandoned public space in Downtown Curitiba), and NESS (an start up incubator) to visited and listened to a short presentation about the app "Minha Curitiba".

At URBS, we heard a very broad discourse highlighting the idea of Curitiba as an innovative city. The focus seems to be more in an economic development rather than the use of technology in urban governance. Again, as in Glasgow, the strong part of the project is on CCTV for monitoring public transportation system and public space by the police. As in Curitiba, smart means a classical panoptical model for controlling the flow of the city. There is not any great innovation, a few uses of smart objects and an incipient big data intelligent processing. However, the "Cyclists Pocket Square" and Minha Curitiba at NEX are initiatives to produce visibility. But they are not part of Curitiba official project. The Cyclists Pocket Square is a small example of lots of similar initiatives dealing with social networking in Brazil or worldwide. It produces visibility and tension vis à vis smart cities' official narratives. The app "Minha Curitiba" is not yet in use in the city. We saw a presentation based in other cities' experiences. The aim of the project is to boost social movements in a political base to help bottom up initiative. The design is based on a naïve non-official narrative of the potential use by social movements to "fight the power and bad politicians".

Comparing this workshop with Glasgow we can say, despite the local specificities, that a powerful protagonist is the centralised governmental funding (Federal fund in Curitiba case, and UK Bid in Glasgow's case). Both smart cities' initiatives rely in control rooms. And in both cities people are not aware of the initiatives. Glasgow has a more complete smart city model than Curitiba: open data plan (we didn't hear about open data in Curitiba), social apps used in an integrated way, sensors on the streets (few in Curitiba), city dashboards, smart control rooms, among other initiatives... However, the problem remains the same: the lack of public participation and invisibility of the new objects' performance. The importance or relevance of local dimension emerged in a few cases, but was not really embedded in the general discourses and practices. It seems that what most these initiatives have in common is the view of citizen as an abstract entity.

\section{Bristol}


Bristol has an integrated smart city project. In Sept 2015 we visit the project "Bristol is Open" (a Joint Venture between the University of Bristol and Bristol City Council), Bristol Playable City and the Pervasive Media Studios at Watershed (projects that try to show the other side of the smart cities, apart of a narrative of efficiency, sustainability and rationality). The aim is to create the city as an "experimental service," as an "open and programmable city region." Even a driverless car project is in place, in order to develop the technology locally. Bristol is Open project aims to be integrated into Playable City Project that approach the city beyond control, surveillance, and fear aspects subjacent to almost all smart cities' initiatives. We saw locative media urban art projects. They are great examples of experimental ways to question the meaning and expectations of citizens about public space. The Pervasive Media Studio is a wonderful facility to promote this kind of intervention and a closer relationship with place and objects. In this sense, this is the best example of the anti-smart city, or of a "real smart city". These actions appear to materialise the digital and put people at the centre of the process.

In Bristol the relationship with new informational sensitive objects are invisible and imperceptible in the street levels. They tried to materialise the process with a "data visualisation", a sort of digital dome in 3D virtual reality, but it seems to be a way to convince people of the need of smart technologies. The open data project and platform, where data is said to be released almost in its "raw form" to the public on the web, was briefly presented and not much information was given to us on how people are using it, or if they are using it at all. Except in Playable City projects, or on the experiments at Pervasive Media Studio, new objects are invisible to people. But there, the experiences are very marginal. Moreover, this two part (Bristol is Open and Playable City/Pervasive Lab) seem not to talk to much. Even the "citizen sensor box" in Bristol, that will be assembled by the community seems to me more like a way of engaging the citizen to accept technology, rather than giving the citizen a true voice. Public engagement was very limited in the Bristol is Open project.

\section{Visibility, Handiness and Social Contract}

The question that remains in Glasgow, Curitiba and Bristol is the people's invisibility of these projects. In Glasgow, Curitiba, and Bristol, everything seems to vanish on street level, too little is actually seen in a daily base experience. We have indeed initiatives to foster visibility and to question the hegemonic smart city's narrative in Curitiba and Bristol. Playable City, Pervasive Lab, Cyclist Pocket Square and "Minha Curitiba" app, are trying to produce meaning 
through visibility and real experience. In those experiences, play, art, and game are in place to oppose functional and efficient aspects of urban life commonly attached to digital technologies. The emphasis is on deferred time, slowness. They're trying to generate some disruption and diversity, social engagement, digital appropriation, and a sense of place. However, they are marginal and not really integrated to the city's project. Moreover, they are in a too small scale. What marks the visited cities is the public's invisibility (lack of participation) and the invisibility of smart objects.

Let return to Mircea Goergescu, Daniela Popescul, 2015:

Apart from the attackers, invisible communication between the connected objects and their autonomous behaviour might affect our lives, all our lives, in ways which are hard to predict. In IoT, the element going to be identified will be the device, and not the individual. It becomes necessary to anticipate dangers in IoT, but it is difficult and it cannot be successful unless the research effort is continuous.

If we don't deal with the visibility of objects, how can we produce meaning, get a sense of space and engage in communication and politics issues? I would like to point out that this invisibility stresses important political, communicational, and spatial consequences in the realm of the new algorithm governmentality. Here I can go back to the Heidegger's philosophy of technique, and the dimensions of space, communication, and politics ${ }^{7}$.

For Heidegger, Dasein is "being in the world" and this is possible because we relate to things/objects/equipment. This relationship creates the world as a set of complex relationship between subjects and objects. Note that here, Heidegger, critiqued by Latour, is saying that we cannot define subjects without objects, as Latour, Serres, Callon, Law... In "Being and Time" the German philosopher highlight that our relationship with things can be understood in two ways: relationship with things "ready to hand" (things that we use and feel - Zurhanden) and things "present to hand" (things we deal in a more abstract way - Vorhanden). We can think space by these categories as well. By Zuhandenheit (handiness) and the Vorhandenheit (presence-at-hand) Dasein is in the world (OLIVER, 2015). Some scholars translate Zurhanden as "technique," (tool) and Vorhanden as "theory" (science).

On smart cities' projects (such as Glasgow, Curitiba or Bristol), in which, technocratic discourses of IoT and Big Data are in the core, Zuhandenheit (handiness) and Vorhandenheit (presence-at-hand) are given within three ways that play with visibility and invisibility issues:

\footnotetext{
${ }^{7}$ I based my remarks on Oliver Christ (2015).
} 
M2M communication; ordinary objects digitally enhanced, and urban equipment. With M2M, the communication between machines occurs without human intervention. In this case, Dasein doesn't find the object because we have a strong delegation. Objects are communicating in a background, outside our perception. So, here, sense is not being produced, and we can lose the public dimension, the communication process, and the insertion in space and place. It's invisible! People simply don't know what's going on, what data and objects are doing. Or people are an active participant in this project (Vorhandenheit). But as we saw, there is a lack of public participation in our three cities. Here we don't have neither Zurhanden nor Vorhanden.

With digitally enhanced objects in everyday life, such as an intelligent car, a smart refrigerator, a smart watch, or a lamppost, Dasein's relation is in a Zuhandenheit's and Vorhandenheit's modes. It's the same object that we are used to (Zurhanden), but it has a new quality that we can understand (Vorhanden). Like my smart mug's example. This occurs because of the new quality of objects (as we saw earlier). This is clear in the examples of "Minha Curitiba," "Cyclist Pocket Square," in Curitiba, and "Playable City" and "Pervasive Lab," in Bristol where people are dealing with visible objects and understanding their informational quality. So these are objects at hand and for hand. It's Visible. But, unfortunately, those initiatives are not well integrated to the main cities' project. They are marginal and it seems to constituted as a cosmetic layer.

Regarding the urban smart equipment, we are not used to them yet. In a better hypothesis, the intelligent objects and Dasein are in a Vorhandenheit's mode (presence-athand). Here we need a stronger public participation because theses urban equipment is not really in handiness. They have invisible communication's functions (the smart lamp, smart meters, smart traffic light...). If people are active participant in smart city's project, they can be aware of this new info-communication capabilities. But it seems not be the case in our three cities. They are invisible (people don't know that a lamppost is smart or a traffic light is smart) or abstract (Vorhanden), scientific and / or theoretically understood.

As pointed above, people must be aware to act politically. Smart objects and big data are collecting and processing data that will be use to predict things (business, crimes, pollution, political trends...) creating an invisible algorithm governmentality or "algocracy," changing subjectivity and the life in our cities. They are invisible, and not a "matter of concern" (LATOUR, 2015). I can say that in smart cities' initiatives, such those in Glasgow, Curitiba, or Bristol, a new and complex relationship between the subject (Dasein) and the objects is in place. But as I saw, the invisibility is the pattern on these smart cities' project. For sure, we have to investigate deeply each experience, but we can say that in most cases people are an abstract 
entity, space is deterritorialised and objects become or invisibles or a scientific abstract thing, with a small public attention or participation. So, we could argue, based on this experience, that smart cities' initiatives are not addressing a political issue in a strong sense of the word. This way, it's a technocratic project!

So, what happen now with the invisibility of algorithms, with theses new smart objects are combined with a lack of public participation and invisibility in smart cities' projects? New objects are not clearly in handiness. However, they're, through translations, mediation, and delegation, acting upon our existence, changing our cities.

According to Qwen (2015), invisibility can change the principles of Social Contract. It is based on a transparent relationship between government and citizen. This is an agreement in which the state provides goods and services, and the citizen, through the institutions, laws and social norms, legitimise them. But new technologies, acting on the background, without discussions or serious political debate are growing in a broad distrust environment. Therefore, with a process that is not transparent and accountable, the idea of social contract is in danger.

In the three cities visited, we cannot say that the government are doing things in secret, but people are not participating as they've been publicised. The "algocracy" system of those smart cities is collecting data from the smart objects, processing information in the background, without a strong citizen participation or awareness. This lack of transparency can generate, and is already generating, suspicions and insecurities endangering the already weakened social contract (and the trust on public and private's institutions). The recent UK "snoop bill" is an example. It was released to put the secret service on the tracks (by the side of the law), grant mass surveillance and hacking actions. It could be seen as an attempt to maintain the social contract in a clear "algocracy".

If the relationship breaks down between human and nonhuman, there is no more sense and objects, as educators (Diderot), disappear as well. This new form of digital black-boxing can harm democracy if we don't pay attention to the two main questions put at the beginning of my conference: 1 . The agency of new info-communicational objects; and 2. How bring this agency to a matter of concern, politicising the relationship between humans and non humans. As Qwen explains:

If algorithms represent a new ungoverned space, a hidden and potentially everevolving unknowable public good, then they are an affront to our democratic system, one that requires transparency and accountability in order to function. A node of power that exists outside of these bounds is a threat to the notion of collective governance itself. This, at its core, is a profoundly undemocratic 
notion - one that states will have to engage with seriously if they are going to remain relevant and legitimate to their digital citizenry who give them their power

We can think about the new objects in the same way that Friedrich Kittler thought about technology and media. McLuhan said that media is an expression of our selves. He was wrong. In a different way, Kittler teaches us that the true is quite the opposite: We're made by our media, objects and technology. Latour said the same. We cannot think society separating subject from the object. The Social is association. For Latour (2015) "essence is existence and existence is action". So, nothing is ready once and for all. Things, not individual things (always a network black-boxed), but a whole system of things, make us people we are, so we have to thing about the circulation and meaning of things enhance-digitally that is making our informational society and our cities today.

\section{References}

BENNETT, Jane (2010). The Vibrant Matter. A Political ecology of Things. Durham, London: Duke University Press Bristol is Open - http://www.bristolisopen.com

CERP IOT - INTERNET OF THINGS EUROPEAN RESEARCH CLUSTER (2009). Internet of Things: Strategic Research Roadmap. http://www.internet-of-thingsresearch.eu/pdf/IoT_Cluster_Strategic_Resear ch_Agenda_2009.pdf

CHRIST, Oliver (2015). Martin Heidegger's Notions of World and Technology in the Internet of Things age. Asian Journal of Computer and Information Systems (ISSN: 2321 - 5658). Volume 03-Issue 02, April 2015.Curitiba Smart City http://www.microsofttranslator.com/bv.aspx?f rom $=$ pt\&to=en $\& a=h t t p: / / u r b s . c u r i t i b a . p r . g o v$. br/

DE WAAL, M., SOFRONIE, S. ROIBÁS, A. (2012). Internet of Things: what is it? http://www.theinternetofthings.eu/internet-ofthings-what-is-it\%3F. (6 set. 2012).

\section{Referências}

BENNETT, Jane. The Vibrant Matter. A Political ecology of Things. Durham, London: Duke University Press Bristol is Open, 2010. Disponível em: <http://www.bristolisopen. com>.

CERP IOT - INTERNET OF THINGS EUROPEAN RESEARCH CLUSTER (2009). Internet of Things: Strategic Research Roadmap. Disponível em: <http://www. internet-of-things-research.eu/pdf/IoT

Cluster_Strategic_Research_Agenda_2009.pd f>

CHRIST, Oliver. Martin Heidegger's Notions of World and Technology in the Internet of Things age. Asian Journal of Computer and Information Systems (ISSN: 2321 - 5658), v.3, ed.2, abr. 2015. Disponível em: <Curitiba Smart City - http://www.microsofttranslator. $\mathrm{com} / \mathrm{bv} \cdot \operatorname{aspx}$ ?from $=$ pt\&to $=e n \& a=h t t p: / /$ urbs.c uritiba.pr.gov.br>

DE WAAL, M.; SOFRONIE, S.; ROIBÁS, A. Internet of Things: what is it? Disponível em: $<\mathrm{http}$ ://www. theinternetofthings.eu/internetof-things-what-is-it $\% 3 F$. Acesso em: 6 set. 2012. 
FOUCAULT, M (1986). The Care of Self. Volume 3 of The History of Sexuality. NY: Pantheon Books. Future City Glasgow http://futurecity.glasgow.gov.uk

HARMAN, G (2011). The Quadruple Object. Winchester, UK, Washington, USA: Zero Books.

JAMES, W. (1981). Pragmatism. Indianapolis/Cambridge: Hackett Publishing Company.

KARIMOVA \& SHIRKHANBEIK (2015). Society of things: An alternative vision of Internet of things. Cogent Social Sciences, 1: 1115654.

http://dx.doi.org/10.1080/23311886.2015.111 5654

KNORR-CETINA, Karin (2001). Postsocial Relations: Theorizing Sociality in a Postsocial Environment. In Ritzer, G., Smart, B., Handbook of Social Theory. London: Sage.

LATOUR, B (1991). Technology is Society Made Durable. In Law, J. (ed.) A Sociology of Monsters: Essays on Power, Technology and Domination. London: Routledge.

LATOUR, B (1992). Where are the Missing Masses? The Sociology of a Few Mundane Artefacts. In Bijker \& Law (eds.) Shaping Technology/Building Society: Studies in Sociotechnical Change. Cambridge: MIT Press.

LATOUR, B. (2005). Reassembling the Social: An Introduction to Actor-Network Theory. Oxford: Oxford University Press.

LEMOS, A (2016). Sensibilités Performatives. Les nouvelles sensibilités des objets dans les métropoles contemporaines. In Revue Sociétés, Formes

urbaines, $\mathrm{n}^{\circ} 132 / 2016 / 2$, pp. 71-84, Bruxelles: De Boeck.

LUPTON, Deborah. Personal data practices in the age of lively data. Available: SSRN 2636709, 2015a. Available at: <http://papers.ssrn.com/sol3/papers.cfm?abstr
FOUCAULT, M (1986). The Care of Self. In: The History of Sexuality. Nova York: Pantheon Books, 1986, v.3. Disponível em: Future City Glasgow <http://futurecity. glasgow.gov.uk>.

HARMAN, G. The Quadruple Object. Winchester, UK, Washington, USA: Zero Books, 2011.

JAMES, W. Pragmatism. Indianapolis/ Cambridge: Hackett Publishing Company, 1981.

KARIMOVA \& SHIRKHANBEIK (2015). Society of things: An alternative vision of Internet of things. Cogent Social Sciences, 1: 1115654. Disponível em: <http://dx.doi.org/ 10.1080/23311886.2015.1115654>.

KNORR-CETINA, Karin. Postsocial Relations: Theorizing Sociality in a Postsocial Environment. In: RITZER, G., SMART, B., Handbook of Social Theory. London: Sage, 2001.

LATOUR, B. Technology is Society Made Durable. In: LAW, J. (ed.). A Sociology of Monsters: Essays on Power, Technology and Domination. London: Routledge, 1991.

LATOUR, B. Where are the Missing Masses? The Sociology of a Few Mundane Artefacts. In: BIJKER \& LAW (eds.) Shaping Technology/Building Society: Studies in Sociotechnical Change. Cambridge: MIT Press, 1992.

Reassembling the Social: An Introduction to Actor-Network Theory. Oxford: Oxford University Press, 2005.

LEMOS, A. Sensibilités Performatives. Les nouvelles sensibilités des objets dans les métropoles contemporaines. In : Revue Sociétés, Formes

urbaines, n.132/2016/2, p.71-84. Bruxelles: De Boeck, 2016.

LUPTON, Deborah. Personal data practices in the age of lively data. SSRN 2636709, 2015a. Disponível em: <http://papers.ssrn.com/sol3/ 
act_id=2636709>. Accessed on: 10 Jan. 2015. papers.cfm?abstract_id=2636709>. Acesso em: 10 jan. 2015.

MANOVICH, Lev. Software takes command. New York: Bloomsburry Academic, 2013 MANOVICH, Lev. Software takes command. New York: Bloomsburry Academic, 2013.

MILLER, D (2010). Stuff. Cambridge: Wiley, John \& Sons.

MILLER, D (2010). Stuff. Cambridge: Wiley, John \& Sons, 2010.

OWEN, Taylor (2015). The violence of algorithm. Foreign Affairs. https://www.foreignaffairs.com/articles/201505-25/violence-algorithms

OWEN, Taylor. The violence of algorithm. Foreign Affairs, 2015. Disponível em: < https://www.foreignaffairs.com/articles/201505-25/violence-algorithms>. 